\title{
Corporate Social Responsibilities Performed by leading Private Commercial Banks in Bangladesh.
}

\author{
Md. Faykuzzaman Mia \\ Lecturer, Department of Accounting \& Information Systems Bangabandhu Sheikh Mujibur Rahman Science \& \\ Technology University Gopalganj-8100. Bangladesh.
}

\begin{abstract}
This paper attempts and explores to represent the present scenario of Corporate social responsibilities (CSR) practice in private commercial banks of Bangladesh. It also examines the banking personnel's perceptions regarding the importance of CSR. In keeping with global movement, CSR is being seen as the source of new competition edge for the banking sectors of Bangladesh. Banks of Bangladesh practices CSR not only to improve community relations but also as source of significant commercial benefit. The study reveals that CSR is important as a tool to gain competitive advantages and has positive impact on employees behavior, customers behavior and establishing a bank's image but CSR practices is not diversified rather than banks are only concerned with some specific areas of CSR. The study can help banking authority understand what should be done for the benefits of customers and the community for sustainability.
\end{abstract}

Keywords: Corporate Social Responsibility, Private commercial Banks, Donation

\section{Introduction}

The Corporate Social Responsibility (CSR) movement has assembled great thrust over the ancient integer of ages and today CSR is surfacing gradually and gaining its acceptance by businesses across the world. For being reason CSR is one of the most conversed topics to the government, by nongovernment and by business itself. The old proverb, "Everybody talks about society, but nobody does anything about it" is not valid in this century because Almona, C. P.(2005) alleged that the role of business worldwide and specifically in the developed economies has evolved over the last few decades from classical 'profit maximizing' approach to a social responsibly approach, where businesses are not only responsible to its stockholders but also to all of its stakeholders in a broader inclusive sense. One can identify so many reasons for shifting the role of business from classical concept to a responsible business concept, but negative impression of stakeholders on the enterprise would get a higher priority among others. In one hand, enterprises create wealth and job opportunities for the society and on the other; they pollute and destroy environment and ecology with devastating impact on human health and biodiversity worldwide. As earlier the researchers said that CSR practices are found in government, non-government and business sectors. Now the banking sectors are not out of the area of business world because it has direct or indirect relationship to the government, non-government and business sectors. The banking sector of Bangladesh involves of private commercial banks, public commercial banks and specialized banks. Where there are more than thirty private commercial banks; dominating Bangladesh's financial sectors. The research has emphasized on private commercial banks because the research topic covers CSR practices of private commercial banks in Bangladesh. Now the banking sectors especially private commercial banking sectors are very competitive. To get this competitive advantage from their rival, CSR is one of the main instruments. CSR is now considered as an integral part of today's businesses. Sarker M.F.H (2012) also argued that in the contemporary globally competitive market companies must portray themselves as socially responsible companies. In their study, they also pointed out that; Corporate Social Responsibility (CSR) can increase both long term profitability and sustainability of the company as well as enhance the reputation of the organization. Islam, S., (2012) mentioned CSR helps the banks to ensure more competitive and reduces the risk of sudden damage of reputation, as CSR is also helpful in building corporate reputation. Bangladesh Bank, the main regulatory authority of banking sector of Bangladesh has also taken some initiatives to formalize CSR in the banking industry. But still we are lagging behind in this regard, in compare to developed countries . Private commercial banks are now practicing CSR as their routine work and are also performing very well. The amount that the banks are expending in this purpose is increasing gradually. In terms of direct monetary expenditure, engagements of banks in CSR initiatives are increasing. This research takes challenge to mention the CSR practices of bank especially private commercial banks in Bangladesh. Now a day Bangladesh Bank (Central bank of Bangladesh) is very concern toward CSR. There are some initiatives taken by Bangladesh bank for practicing CSR activities. Such as encourage private commercial banks in CSR activities for this NBR issued rules on tax rebate for CSR activities. There are challenges to implement CSR properly in Bangladesh. (Azim A \& Islam, 2009) thought currently in Bangladesh, CSR is a matter of self-interest for the corporate sector. Ultimately CSR practices should be better practiced in Bangladesh for better and enhanced performance. 


\section{Literature Review}

In recent times, the most-talking terminology is the corporate social responsibility. It is preventing by corporate world, commercial community and capitalistic industry. It is becoming one of the determining factors for market access. According to the United Nations Industrial Development Organization, "corporate social responsibility understood as being economic, environmental and social imperatives (Triple-Bottom-LineApproach), while at the same time address the expectation of shareholders and stakeholders. Corporate social responsibility is a concept whereby companies integrate social and environmental concerns in their business operations and their interactions with their stakeholders on a voluntary basis. Green paper ( 2001) identified that social responsibility means not only fulfillment legal expectations but also going beyond compliance and investing ' more' into human capital, the environment and in rapport-building of activity. Kok et. al ( 2001) told that corporate social responsibility is the obligation of the firm to use its resources in ways to benefit society, through committed participation as a member of society, taking into account the society at large and improving the welfare of society at large independently of direct gains of the company. Smith (2002) pointed out that corporate social responsibility is the integration of business operations and values whereby the interests of all stakeholders, including customers, employees, investors, and the environment are reflected in the organization's policies and actions. Dusuki and Dar (2005) identifies several driving forces behind the growing trend towards CSR initiatives like growing market pressure on social and ethical issues, regularity pressure, increased power of communication etc.. This is true that banks are paying more to their CSR activities but not so much as their earning increase. Common CSR practices in Bangladesh by different Organization are centered on mainly poverty alleviation, healthcare, education, charity activates, cultural enrichment, youth development, women empowerment, patronizing sports and music etc. (Alam et al. 2010)Sharma (2011) in a study named CSR Practices and CSR Reporting in Indian banking sector mention CSR recognizes an organization's commitment to operate in a socially responsible manner. But CSR activities of developing nations are not so rosy. Particularly in financial sector there is an absence of stringent provisions regarding compliances and reporting CSR. Wise and Ali (2009) In a paper entitled Corporate Governance and Corporate Social Responsibility in Bangladesh with special reference to commercial banks pointed out that corporate Social Responsibility is associated with corporate governance and ethical business procedure. Good corporate governance is expected to under pin effective and efficient corporate social responsibility within firms. Masud and Hossain (2012) conduct a survey among 10 commercial banks and found that 100 banks reported their CSR activities but $60 \%$ banks participated in prescribe CSR area according to financial act. The literature recognizes that CSR practices differ from country to country (Adams, Hill \& Robert, 1998) and between developed and developing countries (Imam, 2000). Furthermore, the nature and patterns of CSR vary between types of industry (Gray et al., 2001)

\section{Objectives of the Study}

The main objective of this study is to explore the corporate social responsibilities of the Banks in Bangladesh and to evaluate the performances of the sample banks in this regard. Specifically this study will consider:

I. To explore the CSR activities of the private commercial banks.

II. To compare and analyze the contribution of CSR activities of private commercial banks in Bangladesh in different areas.

III.To find out the major areas where CSR activities are performing by private commercial banks in Bangladesh.

\section{Methodology of the Study}

This study is exclusively a descriptive research and thus it is purely base on the information from the secondary data. The author has taken ten leading private commercial banks of Bangladesh such as Dutch Bangla Bank Ltd (DBBL),Islami Bank Bangladesh Ltd, Al-Arafah Islami Bank Ltd, Export Import Bank Ltd, First Security Islami Bank Ltd, Pubali Bank Ltd, Union Bank Ltd, Mercantile Bank Ltd, Prime Bank Ltd, United Commercial Bank Ltd as sample size in this study. The secondary data has been collected from the following sources:

Annual Reports of the Banks

Website of the banks

Published different books, articles, journals, magazines, etc.

\section{Meaning Of Corporate Social Responsibility}

Corporate social responsibility (CSR) is a business approach that contributes to sustainable development by delivering economic, social and environmental benefits for all stakeholders. CSR is a concept with many definitions and practices. The way it is understood and implemented differs greatly for each company and country. Moreover, CSR is a very broad concept that addresses many and various topics such as human rights, corporate governance, health and safety, environmental effects, working conditions and contribution to economic development. Whatever the definition is, the purpose of CSR is to drive change towards 
sustainability. Although some companies may achieve remarkable efforts with unique CSR initiatives, it is difficult to be on the forefront on all aspects of CSR. Considering this, the example below provides good practices on one aspect of CSR - environmental sustainability. Corporate social responsibility usually refers to the objectives or motives that should be given weight by the business in addition to those dealing with economic performance (e.g. profits).

\section{Dimensions of Corporate Social Responsibility}

There are two dimensions of corporate social responsibility. These are as follows:

$\square$ Internal dimension: The corporate social responsibility has some internal dimensions such as human resources management, health and safety at work, adaptation to change and management of environmental impact and natural resources.

External dimensions: The corporate social responsibility has some external dimensions such as local communities, business partners, suppliers and customers, human rights, and global environmental concerns.

Importance of Practicing Corporate Social Responsibility

The era of the social enterprises is upon us. More so than ever before, the most successful, respected, and desirable businesses exist to do much more than make money; they exist to use the power of business to solve social and environmental problems. "CSR policies need to be considered as a core and inseparable component of the overall service or product offering." Study after study has shown that socially responsible businesses not only provide sustainable business models, but also have improved marketing, employee recruitment, employee satisfaction, legal treatment, customer loyalty, brand perception, and richer partnerships.

The top five reasons to have (and/or work for) a socially responsible business are:

\section{Employees demand their company to be socially responsible}

Five years ago, it was considered good if a company simply did not harm the environment. However, times have changed, and now employees demand that their company do more than simply not be bad. They need to do good, too. According to Forbes:

(a) $32 \%$ of employees would seriously consider leaving their job if their company gave no / little money to charity;

(b) $65 \%$ would seriously consider leaving their job if their company harmed the environment;

(c) $83 \%$ would seriously consider leaving their job if their employer used child labor in sweatshop factories.
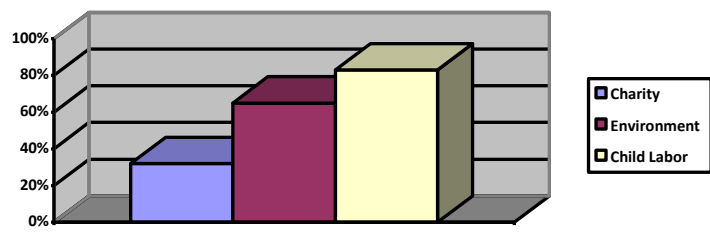

Graph: Reasons of employee leave their job

\section{Consumers expect better business practices (and will pay for it)}

Just under a year ago, a study was published showing that the average consumer will drive en extra 11 minutes to buy a product that supported a cause. Since then, more data has been released supporting the fact that consumers will adjust buying behavior from average companies to socially responsible companies. According to the same article by Forbes:

(a)More than $88 \%$ of consumers think companies should try to achieve their business goals while improving society and the environment;

(b) $83 \%$ of consumers think companies should support charities and nonprofits with financial donations.

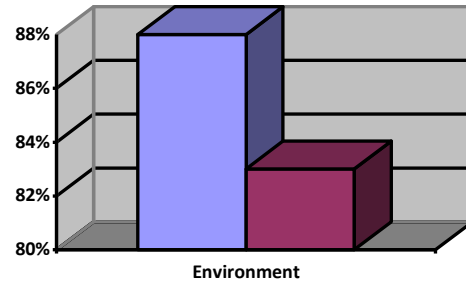

Environment

QDonation

3. It creates competitive immunity (and makes your business more sustainable in the long-term) According to the Harvard Business Review, 
"Strategy... is about choosing a unique position - doing things differently from competitors... These principles apply to a company's relationship to society as readily as to its relationship to its customers and rivals". Furthermore "CSR can be much more than a cost, a constraint, or a charitable deed - it can be a source of opportunity,innovation, and competitive advantage." In addition to helping companies differentiate themselves in an already crowded marketplace, social responsibility also inspires innovation within corporations thereby developing longer-term immunity and business sustainability.

\section{Capitalism is evolving, and society is, too}

Even investors are pulling away from companies that don't do go. This was recently evidenced when investment firms and stockbrokers pulled money away from BP due to its operations in Alaska. In addition to market reactions, society as a whole is also evolving. In the article titled The For Benefit Enterprise, Hareed Sabetti notes that new trends are supporting these businesses, including "Public policy, financial markets, accounting standards, and professional services." As a result, Hareed predicts that "We will see the emergence of a fourth sector of the economy, interacting with but separate from governments, nonprofits, and for-profit businesses.

\section{It is a moral imperative}

Nobody is better positions to create long-term, sustainable change than businesses. According to Michael E. Porter and Mark R. Kramer at the Harvard Business Review "When a well-run business applies its vast resources, expertise, and management talent to problems that it understands and in which it has a stake, it can have a greater impact on social good than any other institution or philanthropic organization. Since businesses have the greatest potential to improve the health of our planet and citizens, as they become prosperous, they have a moral obligation to improve the conditions of a system that has helped them succeed.

\section{Corporate Social Activities of the Leading Private Commercial Banks of Bangladesh}

Table-1: Area of Corporate Social Activities(List) of the leading private commercial banks of Bangladesh.

\begin{tabular}{|l|l|l|}
\hline Sl. & Bank Name & \multicolumn{1}{|c|}{ Area of Expenditure } \\
\hline 1. & Dutch Bangla Bank Ltd (DBBL). & $\begin{array}{l}\text { a) Education. b) Health. c) Disaster management } \\
\text { d) Sports. e) Environment f) Infrastructure development }\end{array}$ \\
\hline 2. & Islami Bank Bangladesh Ltd (IBBL) & $\begin{array}{l}\text { a) Education. b) Health. c) Disaster management } \\
\text { d) Environment. e) Sports f) Culture }\end{array}$ \\
\hline 3. & Al-Arafah Islami Bank Ltd) & $\begin{array}{l}\text { a) Education. b) Health. c) Disaster management } \\
\text { d) Environment. e) Culture }\end{array}$ \\
\hline 5. & Export Import Bank Ltd (EXIM) & $\begin{array}{l}\text { a) Education. b) Health. c) Disaster management } \\
\text { d) Sports e) Culture f) Others }\end{array}$ \\
\hline 6. & First Security Islami Bank Ltd (FSIBL) & $\begin{array}{l}\text { a) Education. b) Health. c) Disaster management } \\
\text { d) Sports. e) Environment f) Others }\end{array}$ \\
\hline 7. & Union Bank Ltd.( UCBL) & $\begin{array}{l}\text { a) Education. b) Health. c) Disaster management } \\
\text { d) Culture e) Others }\end{array}$ \\
\hline 8. & Mercantile Bank Ltd. (MBL) & $\begin{array}{l}\text { a) Education. b) Health. c) Disaster management } \\
\text { d) Others }\end{array}$ \\
\hline 10. & $\begin{array}{l}\text { a) Education. b) Health. c) Disaster management } \\
\text { d) Culture e) Others }\end{array}$ \\
\hline
\end{tabular}


Corporate Social Responsibilities performed by leading Private Commercial Banks in Bangladesh.

Direct CSR Expenditures of the leading private commercial banks of Bangladesh. (January -2015 to December 2015) Amount in Crore)

\begin{tabular}{|c|c|c|c|c|c|c|c|c|c|c|}
\hline $\begin{array}{l}5 \\
L\end{array}$ & Name of Bank & Education & Health & $\begin{array}{l}\text { Disaster } \\
\text { managemeat }\end{array}$ & $\begin{array}{l}\text { Environ- } \\
\text { ment }\end{array}$ & Culture & $\begin{array}{l}\text { Infin-structure } \\
\text { development }\end{array}$ & Sports & Others & Total \\
\hline 1 & $\begin{array}{l}\text { Dutch Bangla } \\
\text { Bank LAd }\end{array}$ & $\begin{array}{l}61.01 \\
(67.65 \%)\end{array}$ & $\begin{array}{l}19.47 \\
(21.59 * 6)\end{array}$ & $\begin{array}{l}3.97 \\
(4.40 \% 9)\end{array}$ & $\begin{array}{l}0.15 \\
(0.1796)\end{array}$ & $\begin{array}{l}0.45 \\
\left(0.50^{\circ}\right)\end{array}$ & $\begin{array}{l}2.60 \\
(2.88 \% 9)\end{array}$ & $\begin{array}{l}1.89 \\
(210 \%)\end{array}$ & $\begin{array}{l}0.64 \\
(0.71 \%)\end{array}$ & 90.18 \\
\hline 2 & $\begin{array}{l}\text { Istami Bank } \\
\text { Bangladesh Led }\end{array}$ & $\begin{array}{l}1753 \\
(21.9006)\end{array}$ & $\begin{array}{l}22.60 \\
(28.24 \%)\end{array}$ & $\begin{array}{l}32.39 \\
(40.47 \%)\end{array}$ & $\begin{array}{l}2.15 \\
(2.699 \%)\end{array}$ & $\begin{array}{l}3.17 \\
(3.609 a)\end{array}$ & $\begin{array}{l}0.86 \\
(1.07 \%)\end{array}$ & $\begin{array}{l}1.00 \\
(1.25 \%)\end{array}$ & $\begin{array}{l}0.34 \\
(0.43 \%)\end{array}$ & 80.04 \\
\hline 3 & $\begin{array}{l}\text { Al-Arafah } \\
\text { Islami Bank } \\
\text { Ltd) }\end{array}$ & $\begin{array}{l}1.32 \\
(4.90 \%)\end{array}$ & $\begin{array}{l}15.45 \\
(7811 \%)\end{array}$ & $\begin{array}{l}1.24 \\
(3.96 \% \text { ) }\end{array}$ & $\begin{array}{l}0.18 \\
(0.58 \%)\end{array}$ & $\begin{array}{l}0.67 \\
(2.14 \%)\end{array}$ & $\begin{array}{l}0.80 \\
(2.56 \% \%)\end{array}$ & $\begin{array}{l}020 \\
(064 \%)\end{array}$ & $\begin{array}{l}0.27 \\
(0.86 \%)\end{array}$ & 3128 \\
\hline 4 & $\begin{array}{l}\text { Export Import } \\
\text { Bank Lid }\end{array}$ & $\begin{array}{l}2.31 \\
\text { (15.37\%) }\end{array}$ & $\begin{array}{l}0.74 \\
(4.81 \%)\end{array}$ & $\begin{array}{l}8.93 \\
(57.06 \% 6)\end{array}$ & 0.00 & $\begin{array}{l}0.80 \\
(5.11 \%)\end{array}$ & 0.00 & $\begin{array}{l}1.00 \\
(6.39 \%)\end{array}$ & $\begin{array}{l}0.76 \\
(4.86 \%)\end{array}$ & 15.65 \\
\hline 5 & $\begin{array}{lr}\text { Finst } & \text { Security } \\
\text { lilami } & \text { Bank } \\
\text { Ltd } & \\
\end{array}$ & $\begin{array}{l}1.39 \\
9.81 \% \text { ay }\end{array}$ & $\begin{array}{l}0.31 \\
(2.19 \%)\end{array}$ & $\begin{array}{l}7.93 \\
(5596 \% 6)\end{array}$ & $\begin{array}{l}0.35 \\
(2.47 \%)\end{array}$ & $\begin{array}{l}3.71 \\
(26.18 \% 6)\end{array}$ & 0.00 & 0.00 & $\begin{array}{l}0.58 \\
(4.0999)\end{array}$ & 1417 \\
\hline 6 & $\begin{array}{l}\text { Pubali Bank } \\
\text { Ltd. }\end{array}$ & $\begin{array}{l}0.83 \\
(10.8596)\end{array}$ & $\begin{array}{l}5.55 \\
(72.55 \%) \\
\end{array}$ & $\begin{array}{l}2.56 \\
(33.46 \%)\end{array}$ & 0.00 & $\begin{array}{l}0.68 \\
(8.8996) \\
\end{array}$ & 0.00 & 0.00 & $\begin{array}{l}0.45 \\
(5.85 \%) \\
\end{array}$ & 7.65 \\
\hline 7 & $\begin{array}{l}\text { Union Bank } \\
\text { Ltd }\end{array}$ & $\begin{array}{l}3.32 \\
(30.4096)\end{array}$ & $\begin{array}{l}0.72 \\
(6.599 \%)\end{array}$ & $\begin{array}{l}6.67 \\
(61.0890)\end{array}$ & 0.00 & $\begin{array}{l}0.10 \\
(0.92 \%)\end{array}$ & $\begin{array}{l}0.01 \\
(0.09 \% 9)\end{array}$ & 0.00 & $\begin{array}{l}0.10 \\
(0.92 \%)\end{array}$ & 10.92 \\
\hline 8 & $\begin{array}{l}\text { Mercantile } \\
\text { Bank LAd. }\end{array}$ & $\begin{array}{l}1.69 \\
\left(18.11 v_{6}\right)\end{array}$ & $\begin{array}{l}4.92 \\
(52.730 \%)\end{array}$ & $\begin{array}{l}1.73 \\
(18.54 \%)\end{array}$ & 0.00 & $\begin{array}{l}0.73 \\
(7.82 \%)\end{array}$ & 0.00 & 0.00 & $\begin{array}{l}0.26 \\
(2.799 \text { ) }\end{array}$ & 9.33 \\
\hline 9 & $\begin{array}{l}\text { Prime Bank } \\
\text { Lid. }\end{array}$ & $\begin{array}{l}17.84 \\
(75.09 \%\end{array}$ & $\begin{array}{l}1.51 \\
(6369 \%)\end{array}$ & $\begin{array}{l}0.93 \\
(3.91 \%)\end{array}$ & 0.00 & $\begin{array}{l}100 \\
(421 \%)\end{array}$ & $\begin{array}{l}100 \\
(4.21 \%)\end{array}$ & $\begin{array}{l}118 \\
(497 \%)\end{array}$ & $\begin{array}{l}0.30 \\
(1.26 \%)\end{array}$ & 23.76 \\
\hline $\begin{array}{l}1 \\
0\end{array}$ & $\begin{array}{l}\text { United } \\
\text { Commercial } \\
\text { Bank } \\
\text { Ltd. }\end{array}$ & $\begin{array}{l}0.64 \\
(8.08 \%)\end{array}$ & $\begin{array}{l}0.30 \\
(3.79 \%)\end{array}$ & $\begin{array}{l}3.93 \\
(49.62 \%)\end{array}$ & $\begin{array}{l}1.00 \\
(12.62 \%)\end{array}$ & $\begin{array}{l}0.29 \\
(3.66 \%)\end{array}$ & $\begin{array}{l}0.75 \\
(9.47 \%)\end{array}$ & 0.00 & $\begin{array}{l}1.00 \\
(12.624 \%) \\
\text { Activat }\end{array}$ & 7,92 \\
\hline
\end{tabular}

( January -2016 to December 2016, Amount in Crore )

\begin{tabular}{|c|c|c|c|c|c|c|c|c|c|c|}
\hline $\begin{array}{l}S \\
L\end{array}$ & $\begin{array}{l}\text { Name of } \\
\text { Bank }\end{array}$ & Education & Health & $\begin{array}{l}\text { Disaster } \\
\text { management }\end{array}$ & $\begin{array}{l}\text { Environ- } \\
\text { ment }\end{array}$ & Culture & $\begin{array}{l}\text { Infra- } \\
\text { structure } \\
\text { development }\end{array}$ & Sports & Others & Total \\
\hline 1 & $\begin{array}{l}\text { Dutch } \\
\text { Bangla } \\
\text { Bank Ltd }\end{array}$ & $\begin{array}{l}60.38 \\
(72.04 \%)\end{array}$ & $\begin{array}{l}6.18 \\
(7.37 \%)\end{array}$ & $\begin{array}{l}9.65 \\
(11.51 \%)\end{array}$ & $\begin{array}{l}0.06 \\
(0.07 \%)\end{array}$ & 0.00 & $\begin{array}{l}1.12 \\
(1.34 \%)\end{array}$ & $\begin{array}{l}2.17 \\
(2.59 \%)\end{array}$ & $\begin{array}{l}4.27 \\
(5.09 \%)\end{array}$ & 83.82 \\
\hline 2 & $\begin{array}{l}\text { Islami Bank } \\
\text { Bangladesh } \\
\text { Ltd }\end{array}$ & $\begin{array}{l}16.00 \\
(23.85 \%)\end{array}$ & $\begin{array}{l}1.68 \\
(2.50 \%)\end{array}$ & $\begin{array}{l}42.6 \\
(63.51 \%)\end{array}$ & $\begin{array}{l}2.64 \\
(3.94 \%)\end{array}$ & $\begin{array}{l}0.02 \\
(0.03 \%)\end{array}$ & 0.00 & $\begin{array}{l}1.73 \\
(2.58 \%)\end{array}$ & $\begin{array}{l}2,32 \\
(3.46 \%)\end{array}$ & 67.08 \\
\hline 3 & $\begin{array}{l}\text { Al-Arafah } \\
\text { Islami Bank } \\
\text { Ltd) }\end{array}$ & $\begin{array}{l}0.97 \\
(9.20 \%)\end{array}$ & $\begin{array}{l}6.46 \\
(61.29 \%)\end{array}$ & $\begin{array}{l}2.32 \\
(22.01 \%)\end{array}$ & $\begin{array}{l}0.58 \\
(5.50 \%)\end{array}$ & $\begin{array}{l}0.21 \\
(1.99 \%)\end{array}$ & 0.00 & 0.00 & 0.00 & 10.54 \\
\hline 4 & $\begin{array}{l}\text { Export } \\
\text { Import Bank } \\
\text { Ltd }\end{array}$ & $\begin{array}{l}19.00 \\
(42.74 \%)\end{array}$ & $\begin{array}{l}1.05 \\
(2.36 \%)\end{array}$ & $\begin{array}{l}21.18 \\
(47.64 \%)\end{array}$ & 0.00 & $\begin{array}{l}1.49 \\
(3.35 \%)\end{array}$ & 0.00 & 0.00 & $\begin{array}{l}1.74 \\
(3.91 \%)\end{array}$ & 44.46 \\
\hline 5 & $\begin{array}{l}\text { First } \\
\text { Security } \\
\text { Islami Bank } \\
\text { Ltd } \\
\end{array}$ & $\begin{array}{l}3.34 \\
(13.49 \%)\end{array}$ & $\begin{array}{l}0.01 \\
(0.04 \%)\end{array}$ & $\begin{array}{l}11.56 \\
(46.69 \%)\end{array}$ & $\begin{array}{l}0.16 \\
(0.65 \%)\end{array}$ & $\begin{array}{l}0.10 \\
(0.40 \%)\end{array}$ & 0.00 & $\begin{array}{l}3.34 \\
(13.49 \%)\end{array}$ & $\begin{array}{l}6.25 \\
(25.24 \%)\end{array}$ & 24.76 \\
\hline 6 & $\begin{array}{l}\text { Pubali Bank } \\
\text { Ltd. }\end{array}$ & $\begin{array}{l}0.73 \\
(14.09 \%) \\
\end{array}$ & $\begin{array}{l}0.99 \\
(19.11 \%)\end{array}$ & $\begin{array}{l}3.03 \\
(58.49 \%) \\
\end{array}$ & 0.00 & $\begin{array}{l}0.02 \\
(0.39 \%)\end{array}$ & 0.00 & 0.00 & $\begin{array}{l}0.42 \\
(8.11 \%) \\
\end{array}$ & 5.18 \\
\hline 7 & $\begin{array}{l}\text { Union Bank } \\
\text { Ltd }\end{array}$ & $\begin{array}{l}0.21 \\
(1.82 \%)\end{array}$ & $\begin{array}{l}0.02 \\
(0.17 \%)\end{array}$ & $\begin{array}{l}9.26 \\
(80.45 \%)\end{array}$ & 0.00 & 0.00 & 0.00 & 0.00 & $\begin{array}{l}2.01 \\
(17.46 \%)\end{array}$ & 11.51 \\
\hline 8 & $\begin{array}{l}\text { Mercantile } \\
\text { Bank Ltd. }\end{array}$ & $\begin{array}{l}1.76 \\
(26.31 \%) \\
\end{array}$ & $\begin{array}{l}1.09 \\
(16.29 \%)\end{array}$ & $\begin{array}{l}3.37 \\
(50.37 \%)\end{array}$ & 0.00 & $\begin{array}{l}0.27 \\
(4.04) \\
\end{array}$ & 0.00 & 0.00 & $\begin{array}{l}0.20 \\
(2.99 \%) \\
\end{array}$ & 6.69 \\
\hline 9 & $\begin{array}{l}\text { Prime Bank } \\
\text { Ltd. }\end{array}$ & $\begin{array}{l}5.70 \\
(32.19 \%) \\
\end{array}$ & $\begin{array}{l}1.52 \\
(8.58 \%) \\
\end{array}$ & $\begin{array}{l}0.76 \\
(4.29 \%) \\
\end{array}$ & 0.00 & $\begin{array}{l}6.02 \\
(33.99 \%)\end{array}$ & 0.00 & $\begin{array}{l}1.03 \\
(5.82 \%) \\
\end{array}$ & $\begin{array}{l}2.68 \\
(15.13 \%) \\
\end{array}$ & 17.71 \\
\hline $\begin{array}{l}1 \\
0\end{array}$ & $\begin{array}{l}\text { United } \\
\text { Commercial } \\
\text { Bank Ltd. }\end{array}$ & $\begin{array}{l}0.41 \\
(4.26 \%)\end{array}$ & $\begin{array}{l}0.27 \\
(2.80 \%)\end{array}$ & $\begin{array}{l}6.62 \\
(68.74 \%)\end{array}$ & 0.00 & 0.00 & 0.00 & $\begin{array}{l}0.28 \\
(2.91 \%)\end{array}$ & $\begin{array}{l}2.07 \\
(21.50 \%)\end{array}$ & 9.63 \\
\hline
\end{tabular}




\section{Recommendations}

The following measures are suggested to the authorities of the leading private commercial banks of Bangladesh to enhance their corporate social activities:

$\square$ The authority of the Al-Arafah Islami Bank Ltd, Export Import Bank Ltd and First Security Islami Bank Ltd should give more emphasis on the corporate social activities specially in Culture, Environment, Social welfare, Infrastructure development in the future if the authority of the bank wants to attract customers to the products and services of the bank.

$\square$ Although the corporate social activities of the Dutch Bangla Bank Ltd and Islami Bank Bangladesh Ltd are comparatively good than other private commercial banks of Bangladesh but the authorities of the bank should explore more fields specially in Culture, Environment, Social welfare, Infrastructure development, clean water management, forestation, Beautifications of cities, waste management, and old person's homes, accommodation for the slum dwellers, women's rights and anti-dowry practices where they can contribute to develop the society that will help them to attract prospective customers to their products and services

$\square$ The authorities of the Prime Bank Ltd, United Commercial Bank Ltd, Union Bank Ltd, Mercantile Bank Limited, Pubali Bank Ltd should give top priority on the corporate social activities immediately otherwise they may not be able to attract large number of customers to their products and services in the long-run.

$\square$ The authorities of theten leading private commercial banks of Bangladesh should set standard for conducting social responsibilities and should spend a certain portion of their profits regularly as budget for social activities.

$\square$ The authorities of the ten leading private commercial banks of Bangladesh should conduct occasional social audits for using funds properly to reach the social-responsibility goals of the bank.

\section{Conclusion}

Now a days a Company is no more the sole property of its stockholders; rather it is the property of the society. As such banks should increase their participation in different areas to express the society that they are really responsible to them. The study revealed that the overall CSR activities of the sample banks are very poor and most importantly contributions in the area of clean water management, forestation, Beautifications of cities, waste management, and old person's homes, accommodation for the slum dwellers, women's rights and antidowry practices, birth control products etc. are totally absent though they have shown better concentration in education and health related CSR. As the above mentioned areas in which banks have no contribution play significant role in the socio economic development of the country, they must spend more in such areas. The contributions of the banks towards the retention of our culture and heritage, to save environment and to encourage sports are not up to the mark. Hence, banks should increase their contribution in those areas. To motivate the banks to contribute to society government provides tax rebate facility in limited areas which might be extended further to motivate the banks to contribute to the neglected areas. Again, banks are mainly dependent on the customers for collecting fund. So the customers should be more conscious about the CSR of banks and they should prefer those banks which have higher contributions to CSR. It is also to be mentioned that the CSR disclosures is not mandatory in Bangladesh. As it is voluntary in nature, there is no specific guideline to disclose such activities in the annual report. Thus, Bangladesh Security and Exchange Commission (BSEC) should provide a guideline to be followed to disclose CSR related activities at least for the listed companies in Bangladesh. Since, CSR is very important further study should be conducted for motivating companies to contribute in this area. Though utmost efforts have been given to reveal the sector wise CSR activities of the listed banks in Bangladesh, exclusion of factors like how much the banks contribute in a specific area of CSR out of the total fund in that sector and the output derived from their contribution constrained the expected results of the study. In this regard, there is wide scope for future research to find the effect of CSR activities in the socio economic development of Bangladesh as well as survey can be conducted to explore the impact of such activities of banks on their clients in choosing the banks with good CSR performances.

\section{References}

[1]. Adams, Carol, and Zutshi, Ambika, (2006), "Corporate Social Responsibility: Why Business Should Act Responsibility and Be Accountable"

Alam \& Sharma (2010-2011), "CSR Practices and CSR Reporting in Indian Banking sector"

Arif, Anwarul, Azim, (1990), "Social Responsibility of Business" Chittagong University Studies (Commerce), Vol. 6, pp. 73-94.

Dusuki and Dar (2005), "Driving forces behind the growing trend towards CSR"

Hareed Sabetti "Benefit Enterprise"

Masud and Hossain (2012), "Survey of CSR Practice in Bangladesh"

Michael E. Porter and Mark R. Kramer, "Harvard Business Review"

Ruggie, John, G, (2000), “Globalization, the Global Impact and Corporate Social Responsibility”, Transnational, Pp. 291 -294.

Wise and Ali (2009), "Corporate Governance and Corporate Social Responsibility in Bangladesh"

Development of Environment, Government of Bangladesh: www.doe.bd.org

United Nations Environment Programs: www.unep.org

Sustainable Development Networking Program (SDNP) Bangladesh: www.sdnbd.org 
[13]. Bangladesh Bank Website: www.bb.org.bd

[14]. www.dutchbanglabank.com

[15]. www.islamibankbd.com

[16]. www.al-arafahbank.com

[17]. www.eximbankbd.com

[18]. www.fsiblbd.com

[19]._info@pubalibankbd.com

[20]. info.unionbank.com.bd

[21]. www.mblbd.com

[22]. www.primebank.com.bd

[23]. www.ucbl.com

[24]. www.forbes.com 